\title{
Comparative cultural factors and knowledge management and desirable proposal (Applied study: public and private banks of Khorasan Razavi province)
}

\section{Factores culturales comparativos y gestión del conocimiento y propuesta deseable (Estudio aplicado: bancos públicos y privados de la provincia de Khorasan Razavi)}

\author{
Reza Karimi Moghadam \\ Department of Public Administration, Kerman Branch, Islamic Azad University, Kerman, Iran \\ Orcid: https://orcid.org/0000-0001-8894-0977
}

Alireza Manzari Tavakoli

Department of Educational Psychology, Kerman Branch, Islamic Azad University, Kerman, Iran Orcid: https://orcid.org/0000-0003-4271-782X

Sanjar Salajegheh

Department of Public Administration, Kerman Branch, Islamic Azad University, Kerman, Iran Orcid: https://orcid.org/0000-0003-2749-3522

Mohammad Jalal Kamali

Department of Public Administration, Kerman Branch, Islamic Azad University, Kerman Orcid: https://orcid.org/0000-0003-4125-0551

Received 02-08-20 Revised 04-10-20

*Correspondence

Email: a.manzari@iauk.ac.ir
Accepted 01-11-21 On line 01-17-21

Cite as:

Karimi Moghadam, R., Manzari Tavakoli, A.R, Salajegheh, S., \& Kamali, M.J. (2021). Comparative cultural factors and knowledge management and desirable proposal (Applied study: public and private banks of Khorasan Razavi province). Propósitos y Representaciones, 9 (SPE1), e876. Doi: http://dx.doi.org/10.20511/pyr2021.v9nSPE1.876 


\section{Summary}

The aim of this study was to identify and compare the relationship between cultural factors and knowledge management and provide the desired model (comparative study: public and private banks in Khorasan Razavi province). The statistical population of this study included all managers and employees of public and private banks, of which 350 people were selected as a sample. Based on the results, 68 components were identified for 14 components and factors related to it. Factors related to knowledge management are categorized into 9 dimensions and factors related to organizational culture are categorized into 5 dimensions. The results show that there is a positive and significant relationship between knowledge storage indicators, knowledge organization, knowledge dissemination, knowledge absorption, knowledge creation, knowledge application, knowledge evaluation, knowledge removal, and knowledge sharing and cultural factors in public and private banks of Khorasan Razavi province. The results show that cultural factors impact on knowledge management and provide the desired model in public and private banks in Khorasan Razavi province.

Keywords: knowledge management, cultural factors, public and private banking.

\section{Resumen}

El objetivo de este estudio fue identificar y comparar la relación entre los factores culturales y la gestión del conocimiento y proporcionar el modelo deseado (estudio comparativo: bancos públicos y privados en la provincia de Khorasan Razavi). La población estadística de este estudio incluyó a todos los gerentes y empleados de bancos públicos y privados, de los cuales se seleccionaron 350 personas como muestra. Con base en los resultados, se identificaron 68 componentes para 14 componentes y factores relacionados. Los factores relacionados con la gestión del conocimiento se clasifican en 9 dimensiones y los factores relacionados con la cultura organizacional se clasifican en 5 dimensiones. Los resultados muestran que existe una relación positiva y significativa entre los indicadores de almacenamiento del conocimiento, la organización del conocimiento, la difusión del conocimiento, la absorción del conocimiento, la creación del conocimiento, la aplicación del conocimiento, la evaluación del conocimiento, la eliminación del conocimiento y el intercambio de conocimiento y factores culturales en la banca pública y privada. de la provincia de Khorasan Razavi. Los resultados muestran que los factores culturales impactan en la gestión del conocimiento y proporcionan el modelo deseado en los bancos públicos y privados de la provincia de Khorasan Razavi.

Palabras clave: gestión del conocimiento, factores culturales, banca pública y privada.

\section{Introduction}

The current period of human life has been marked by amazing changes and transformations. Almost every organization has undergone a change in its information systems. Today, the status of information systems in terms of speed and variety of communication flows is not comparable to the last ten years. This phenomenon is one of the signs of the information revolution and its increasing importance as the most important strategic resource of the organization has led to the formation of a knowledge-based economy. In general, one of the factors influencing the success of knowledge management in organizations is organizational culture. In fact, organizational culture is the foundation of knowledge management and plays an important role in the failure or success of organizational strategies. The supportive role of organizational culture in knowledge sharing has also been well articulated by knowledge 
management professionals.

\section{Problem Statement}

Believing in the vital role of knowledge in achieving sustainable competitive advantage, organizations try to use new systems to systematically restrain the value of their knowledge assets to achieve strategic goals and to improve their performance. (Shaykh al-Islam et al., 2017).

Today's changing world requires organizations to look for new tools to survive. One of the tools that can help organizations achieve this goal is knowledge management. Knowledge management is a process that helps organizations find important information, select, organize and disseminate, and specializes in activities such as problem-solving, dynamic learning, and decision making (Calipha et al., 2018).

The goal of Knowledge management program in the organization at the right time is to provide appropriate information to the right people at the right time, but the key point is that in each society and organization, the factors influencing the implementation of the knowledge management system, can be different (Canapckin, 2010).

As organizations become more inclined to use the knowledge management system and understanding the importance of investing and succeeding in this field, it is critical for those in charge of implementing knowledge management systems in organizations to understand What are the factors that affect knowledge management in their organization and what is the relationship between them (Fadaei et al., 2018).

Cultural policies are built at the crossroads of culture and politics; while the scope and objectives may change according to space and time, contemporary cultural policies clearly define different ways of life and methods of cultural production, distribution, and consumption in relation to an institutional form of government. Cultural policy, if widely understood, is in the form of tensions between profits and aesthetic value, constant changes between private and public borders, social and cultural inputs and outputs, and so on. In many countries, contemporary cultural policy has important economic and social dimensions. In some formulas, it may include institutional areas such as education, arts, and broadcasting. However, what is important for current purposes is that in the most practical contexts, cultural policy within political systems and the general atmosphere of governments manifests itself; as a result, its relationship to issues of national identity is inseparable (Sharifzadeh et al, 2016).

Among the various business policies, the following are effective in creating the right infrastructure and platform to support the knowledge management process; human resource management policies that focus on attracting and retaining talent, an organizational culture that embraces new ideas and promotes and enhances learning, technical tools that can collect and disseminate knowledge, a strategic approach to knowledge, and finally an organizational structure that facilitates communication and interactions.

Knowledge is increasingly recognized as a vital component for organizations. On the other hand, knowledge is largely based on individuals and group characteristics of individuals in the form of organizational culture and may play a key role in rejecting or accepting knowledge management as an important factor (Moo et al., 2010). To be able to use knowledge efficiently in order to achieve goals quickly, a system of preparation, storage, processing, and dissemination of knowledge must be created to provide access to the required knowledge at any time and place. The solution that has been used by many industries and organizations in recent years is knowledge management. Successful entry into the age of knowledge requires a variety of structural, cultural, technological, and human prerequisites, which has been neglected from many perspectives. 
In this study, the need to achieve a model for the implementation of cultural factors has been pointed out and attention has been paid to the fact that culture cannot be controlled and mechanized and it is not in its best interest to leave it alone; Rather, it is possible and necessary to pay attention to the frequency and complexity of cultural components and variables with an approach derived from chaos management to cultural policy and points out that the balanced assessment model has special capabilities to become a model of cultural policy which this indigenous that it requires increasing efforts of cultural managers and policymakers and commentators and practitioners in this field. Given the above, it can be said that the importance of this research is:

1. The results will play an important role in planning the development of banking affairs in Khorasan Razavi province.

2. Based on the findings, the managers of this organization will manage more effectively.

3. The results will be used by other researchers.

In fact, the main purpose of this research is to compare the relationship between cultural factors and knowledge management and provide the desired model (comparative study: public and private banks in Khorasan Razavi province).

\section{Theoretical foundations the of research}

It seems necessary to have a flexible organizational culture that can support change well to explore, understand, and create the knowledge needed by the organization and disseminate it among the organization's staff. Because the organizational culture of an organization is the identity and personality of that organization. Organizational culture can move the organization forward or stop it. Only by examining, changing, and creating an appropriate and flexible organizational culture can we gradually change the pattern of interaction between people in the organization and use knowledge management as a competitive advantage (Fadaei et al., 2018).

Organizations have concerns about rapid changes in the workplace, which has increased competition between organizations. Therefore, using the current organizational knowledge and guiding it to successful management, can help the organization. Gloucester studies have shown that gaining and disseminating knowledge has had positive and direct effects on performance speed as well as organizational quality. Improving the speed of performance and increasing the quality of performance of an organization increases the level of customer satisfaction, but it will be important how organizational knowledge is managed, and this issue requires knowledge management. According to Delong and Fahey's studies, organizational culture in the following four cases can affect knowledge management: 1 . The role that organizational culture plays in recognizing knowledge and its importance for organizational management, 2 . The role that culture plays in building relationships between knowledge and employees, 3. Cultural patterns that show how knowledge is used in specific situations. And 4. The role of process formation, legalization, and dissemination of knowledge in an organization (Ahmadi et al., 2016).

Managers can plan actions to provide a good platform for knowledge management in the organization. In these measures, organizational culture can be used as a tool to institutionalize knowledge management in the organization. The impact of organizational culture on knowledge management can be examined in three areas: knowledge creation, knowledge management, and knowledge reserves. (Ahmadi et al., 2016). 


\section{Table 1}

The effect of organizational culture on knowledge management

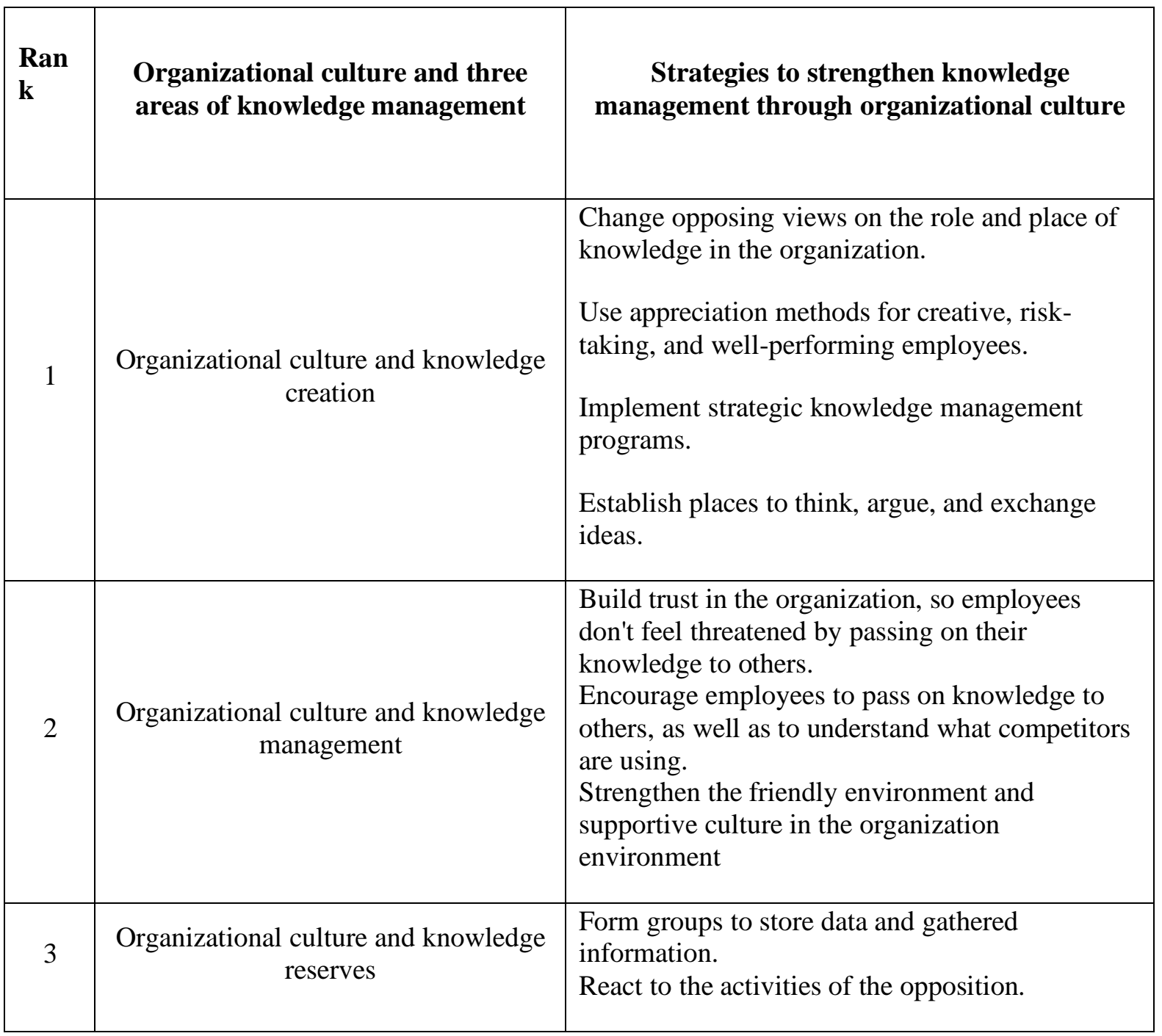

\section{A review of research}

Dehghani, Yaghoubi, Moghli, and Vazifeh (2019) in a study compiled a comprehensive model of factors affecting the effective establishment of knowledge management. The research findings include the development of the concept of knowledge management; introduction of factors related to human resources, structural factors, infrastructural factors, and strategic factors. Finally, a comprehensive model of factors affecting the effective establishment of knowledge management is presented. Milani, Fallah Faramarzi, Bagheri Majd, and Tayari Fard (2019) in a study examined the relationship between participatory culture and knowledge management and their impact on organizational development among employees of Urmia University. The results of the study confirm the impact of participatory culture on organizational participation and organizational development, as well as the impact of knowledge management on organizational development. Khademizadeh, Faraj Pahl,o and Mohammadi (2019) conducted a study on the relationship between organizational culture and knowledge management in the libraries of Shahid Chamran University of Ahvaz. The findings showed that the culture of libraries is a hierarchical culture; there is no significant relationship between this type of culture and knowledge management, but there is a significant relationship between tribal or group 
culture, market culture, and status culture with knowledge management. Also, correlation results showed that group organizational culture has the most correlation with knowledge management. Fadaei, Naghshineh, and Andayesh (2018) in a study examined the relationship between organizational culture and knowledge management. The results showed that commitment to participation, adaptability, versatility, and mission are significant predictors for knowledge management. Francesca et al. (2018) in a study entitled "Towards Social Knowledge Management in a Compressed General Knowledge Organization" stated that knowledge-based organizations can benefit from the introduction of knowledge management procedures. In a study, Polo, Cervai, and Kantola (2018) introduced the concept of educational culture in the organization. The results showed that individual and group training in the organization, according to the characteristics and Specifications of the organization, confirm the good validation indicators in the organization. Understanding education in the organization and improving educational activities according to the organization's cultural policies (under structural, managerial, human, and strategic factors) is recommended. These are the cultural characteristics that enable the organization to develop more effective strategies for education and progress. In a study. In a study, Maria and Costa (2016) examined the understanding of knowledge management in academic libraries. The results showed that although knowledge management professionals are aware of its benefits not only for library performance but also for career options for future professional librarianship and information, and know and enjoy all of its benefits, there is still a lack of transparency on the issue of knowledge management (KM). eventually, academic libraries have taken steps to capture the knowledge of their users and explicit internal knowledge. However, social practices such as practical societies, which involve tacit knowledge and the sharing of expertise, were not used. In a study, Leidener and Wald (2010) assessed the impact of process-oriented, structural, cultural, and organizational factors on the success of knowledge management in the organization. The results showed that in addition to information technology support factors, cultural factors in the organization have a significant impact on the success of knowledge management. It also covers and compensates for cultural factors, lack of routine organizational procedures, and organizational memory.

\section{Methodology}

This research is a type of mixed research in which two approaches used in behavioral sciences, namely quantitative and qualitative, are used. In this research, first the qualitative stage including the background of research and interview with human resources management experts to identify the dimensions, components, and characteristics of knowledge management and cultural factors and then in a small stage through the questionnaire, to determine the current situation, to determine the influential factors. Determining the contribution of each of the influential factors, determining the appropriate degree for the proposed model, and providing an executive mechanism for improvement is used. In the qualitative stage of this study, the statistical population includes experts and elites in the field of management, managers with experience in the administrative system, and management professors who have the appropriate information in the field of knowledge management and cultural factors. A sample of 30 available from the above population was selected and the influential factors were identified using a semi-structured interview. In parallel with that using library method, existing records, including dissertations, research papers, books, and scientific journals, were reviewed and then, using the Delphi method and reusing expert opinions, dimensions, components, and indicators effected knowledge management and cultural factors. In a quantitative stage, the statistical population is all employees and managers of public and private banks in Khorasan province in 2019, a random sample of 350 people (175 people from each public and private banks) were extracted and a questionnaire was formed. A field was distributed among them. In general, the following research steps include reviewing the background of the topic, collecting qualitative data obtained through interviews and library methods, and analyzing qualitative data that lead to qualitative results. Based on the results of the qualitative section, a questionnaire is compiled and distributed. Then little data is collected and analyzed and the final results are obtained. 


\section{Results}

Determining the dimensions, components, and indicators of knowledge management and cultural factors

Table 2

Results of the first round of Delphi method: about the key and effective factors on the optimal model of employees' talent management

\begin{tabular}{|l|c|c|c|}
\hline \multicolumn{1}{|c|}{ Factor description } & Average answers & Kendall & $\begin{array}{c}\text { The order of } \\
\text { importance }\end{array}$ \\
\hline Participatory Culture & 2.57 & 3.72 & 1.00 \\
\hline Trust-based culture & 2.80 & 3.67 & 1.00 \\
\hline Learning culture & 2.42 & 3.76 & 4.00 \\
\hline $\begin{array}{l}\text { Customer orientation } \\
\text { culture }\end{array}$ & 3.80 & 6.66 & 2.00 \\
\hline $\begin{array}{l}\text { Knowledge-driven } \\
\text { leadership }\end{array}$ & 3.37 & 5.09 & 2.00 \\
\hline Creating knowledge & 3.52 & 5.67 & 3.00 \\
\hline Attract knowledge & 3.72 & 6.26 & 3.00 \\
\hline $\begin{array}{l}\text { Organizing } \\
\text { knowledge }\end{array}$ & 4.07 & 7.33 & 5.00 \\
\hline Knowledge storage & 3.60 & 5.86 & 5.00 \\
\hline $\begin{array}{l}\text { Dissemination of } \\
\text { knowledge }\end{array}$ & 4.00 & & \\
\hline $\begin{array}{l}\text { Application of } \\
\text { knowledge }\end{array}$ & 4.12 & & \\
\hline
\end{tabular}

In the table above, the final research indicators, which were designed in the form of a questionnaire, were sent to the experts for evaluation and a summary of the experts' opinions was reported. According to the Kendall index, the desired indicators can be ranked. The lower the Kendall index for different criteria, the higher the significance of this criterion in the final model, and the better the ranking in the criteria to be evaluated. At this stage, the indicators that have the highest amount of Kendall are removed from the list. 
Table 3.

Results of the second round of Delphi method: Results of the second and third rounds of Delphi method: About key and effective factors on knowledge management and cultural factors

\begin{tabular}{|l|c|c|c|c|c|c|}
\hline & \multicolumn{2}{|c|}{ The second round of Delphi } & \multicolumn{2}{c|}{ The third round of Delphi } \\
\hline Factor description & $\begin{array}{c}\text { Average } \\
\text { answers }\end{array}$ & Kendall & $\begin{array}{c}\text { The order } \\
\text { of } \\
\text { importance }\end{array}$ & $\begin{array}{c}\text { Average } \\
\text { answers }\end{array}$ & Kendall & $\begin{array}{c}\text { The order } \\
\text { of } \\
\text { importance }\end{array}$ \\
\hline Participatory Culture & 3.76 & 7.16 & 3 & 3.77 & 7.77 & 2 \\
\hline Trust-based culture & 3.90 & 7.88 & 4 & 3.66 & 7.27 & 2 \\
\hline Learning culture & 3.17 & 4.84 & 1 & 3.66 & 7.52 & 2 \\
\hline $\begin{array}{l}\text { Customer orientation } \\
\text { culture }\end{array}$ & 3.57 & 6.02 & 2 & 3.83 & 8.41 & 3 \\
\hline $\begin{array}{l}\text { Knowledge-driven } \\
\text { leadership }\end{array}$ & 4.00 & 8.05 & 4 & 3.69 & 755 & 2 \\
\hline Creating knowledge & 3.97 & 7.41 & 3 & 3.80 & 7.96 & 2 \\
\hline Attract knowledge & 3.53 & 6.27 & 2 & 3.80 & 795 & 3 \\
\hline $\begin{array}{l}\text { Organizing } \\
\text { knowledge }\end{array}$ & 3.21 & 5.00 & 1 & 3.82 & 8.12 & 3 \\
\hline Knowledge storage & 3.47 & 5.50 & 1 & 3.90 & 8.61 & 3 \\
\hline $\begin{array}{l}\text { Dissemination of } \\
\text { knowledge }\end{array}$ & 3.73 & 7.05 & 3 & 3.90 & 8.79 & 3 \\
\hline $\begin{array}{l}\text { Application of } \\
\text { knowledge }\end{array}$ & 3.87 & 7.14 & 3 & 4.03 & 9.25 & 4 \\
\hline Sharing knowledge & 3.19 & 5.68 & 1 & 3.83 & 8.39 & 3 \\
\hline Eliminate knowledge & 3.41 & 7.43 & 3 & 3.64 & 7.46 & 3 \\
\hline assessment & 6.09 & 2 & 3.45 & 2 & 1 \\
\hline Onowledge & 3.12 & & & & & \\
\hline
\end{tabular}

One of the main purposes of using the Delphi method is to remove excess indicators and add suggested indicators. This means that the proposed criteria are summarized to reach the final result. At this stage, after removing the excess indicators in the previous stage of Delphi, which was done according to the opinion of the experts, the questionnaire was sent to the experts for initial approval.

Comparative study of the situation of knowledge management and cultural factors between public and private banks

For a comparative study of knowledge management situation and cultural factors between 
public and private banks, using the questionnaire data information on the final results of dimensions, components, and influential indicators were examined by the T-test of two independent samples. The results are as follows: 
Table 4.

T-test results of two independent samples for comparative study

\begin{tabular}{|c|c|c|c|c|c|}
\hline \multicolumn{2}{|c|}{ Variable's name } & \multirow{2}{*}{$\begin{array}{c}\text { Average } \\
3.21\end{array}$} & \multirow{2}{*}{$\begin{array}{c}\begin{array}{c}\text { Standard } \\
\text { deviation }\end{array} \\
0.311\end{array}$} & \multirow{3}{*}{$\begin{array}{c}\begin{array}{c}\text { T-Test } \\
\text { statistics }\end{array} \\
-0.840\end{array}$} & \multirow{3}{*}{$\begin{array}{c}\begin{array}{c}\text { Significant } \\
\text { level }\end{array} \\
0.401\end{array}$} \\
\hline \multirow[t]{2}{*}{$\begin{array}{l}\text { knowledge } \\
\text { management }\end{array}$} & $\begin{array}{l}\text { State-owned } \\
\text { banks }\end{array}$ & & & & \\
\hline & $\begin{array}{l}\text { Private } \\
\text { banks }\end{array}$ & 3.24 & 0.316 & & \\
\hline \multirow[t]{2}{*}{$\begin{array}{l}\text { Creating } \\
\text { knowledge }\end{array}$} & $\begin{array}{l}\text { State-owned } \\
\text { banks }\end{array}$ & 3.71 & 0.594 & \multirow{2}{*}{-2.35} & \multirow{2}{*}{0.019} \\
\hline & $\begin{array}{l}\text { Private } \\
\text { banks }\end{array}$ & 3.90 & 0.618 & & \\
\hline \multirow[t]{2}{*}{$\begin{array}{l}\text { Attract } \\
\text { knowledge }\end{array}$} & $\begin{array}{l}\text { State-owned } \\
\text { banks }\end{array}$ & 3.56 & 0.594 & \multirow{2}{*}{0.683} & \multirow{2}{*}{0.495} \\
\hline & $\begin{array}{l}\text { Private } \\
\text { banks }\end{array}$ & 3.52 & 0.618 & & \\
\hline \multirow[t]{2}{*}{$\begin{array}{l}\text { Dissemination } \\
\text { of knowledge }\end{array}$} & $\begin{array}{l}\text { State-owned } \\
\text { banks }\end{array}$ & 3.14 & 0.647 & \multirow{2}{*}{0.840} & \multirow{2}{*}{0.401} \\
\hline & $\begin{array}{l}\text { Private } \\
\text { banks }\end{array}$ & 3.09 & 0.650 & & \\
\hline \multirow[t]{2}{*}{$\begin{array}{l}\text { Organizing } \\
\text { knowledge }\end{array}$} & $\begin{array}{l}\text { State-owned } \\
\text { banks }\end{array}$ & 3.14 & 0.453 & \multirow{2}{*}{0.360} & \multirow{2}{*}{0.719} \\
\hline & $\begin{array}{l}\text { Private } \\
\text { banks }\end{array}$ & 3.12 & 0.437 & & \\
\hline \multirow[t]{2}{*}{$\begin{array}{l}\text { Knowledge } \\
\text { storage }\end{array}$} & $\begin{array}{l}\text { State-owned } \\
\text { banks }\end{array}$ & 3.01 & 0.546 & \multirow{2}{*}{0.336} & \multirow{2}{*}{0.737} \\
\hline & $\begin{array}{l}\text { Private } \\
\text { banks }\end{array}$ & 2.99 & 0.566 & & \\
\hline \multirow[t]{2}{*}{$\begin{array}{l}\text { Application of } \\
\text { knowledge }\end{array}$} & $\begin{array}{l}\text { State-owned } \\
\text { banks }\end{array}$ & 3.10 & 0.812 & \multirow{2}{*}{1.32} & \multirow{2}{*}{0.189} \\
\hline & $\begin{array}{l}\text { Private } \\
\text { banks }\end{array}$ & 2.99 & 0.790 & & \\
\hline \multirow[t]{2}{*}{$\begin{array}{l}\text { Knowledge } \\
\text { assessment }\end{array}$} & $\begin{array}{l}\text { State-owned } \\
\text { banks }\end{array}$ & 3.04 & 0.298 & \multirow{2}{*}{-0.387} & \multirow{2}{*}{0.699} \\
\hline & $\begin{array}{l}\text { Private } \\
\text { banks }\end{array}$ & 3.06 & 0.308 & & \\
\hline
\end{tabular}




\begin{tabular}{|l|l|c|c|c|c|}
\hline $\begin{array}{l}\text { Eliminate } \\
\text { knowledge }\end{array}$ & $\begin{array}{l}\text { State-owned } \\
\text { banks }\end{array}$ & 3.54 & 0.421 & \multirow{2}{*}{0.131} \\
\cline { 2 - 4 } & $\begin{array}{l}\text { Private } \\
\text { banks }\end{array}$ & 3.47 & 0.445 & 0.131 \\
\hline $\begin{array}{l}\text { Sharing } \\
\text { knowledge }\end{array}$ & $\begin{array}{l}\text { State-owned } \\
\text { banks }\end{array}$ & 3.21 & 0.371 & \multirow{2}{*}{0.146} & 0.884 \\
\cline { 2 - 4 } & $\begin{array}{l}\text { Private } \\
\text { banks }\end{array}$ & 3.19 & 0.362 & \\
\hline
\end{tabular}

To compare the status of knowledge management and its sub-indicators between public and private banks, the average of the index between the two communities was compared, and the results obtained from the table show that: In the model, the t-statistic calculated for the indicators is not significant except for knowledge creation at the level of 0.05. Comparing the average of these factors shows that the status of indicators is not significantly different between public and private banks in Khorasan Razavi province, except for the knowledge creation index, which is better in private banks than in state-owned. However, in general, due to the higher average in both communities, the indicators in State-owned and private banks are favorable. 
Table 5.

Priority of ranking

\begin{tabular}{|c|c|c|}
\hline $\begin{array}{c}\text { Average ratings in private } \\
\text { banks }\end{array}$ & Variable & $\begin{array}{c}\text { Average ratings in state- } \\
\text { owned banks }\end{array}$ \\
\hline 6.98 & Creating knowledge & 6.49 \\
\hline 6.47 & Attract knowledge & 6.55 \\
\hline 6.38 & Eliminate knowledge & 4.63 \\
\hline 4.61 & Dissemination of knowledge & 4.67 \\
\hline 4.45 & Application of knowledge & 4.29 \\
\hline 4.33 & Sharing knowledge & 4.07 \\
\hline 3.88 & Knowledge organization & 3.75 \\
\hline 4.09 & Knowledge evaluation & 3.81 \\
\hline 3.81 & Knowledge storage & \\
\hline
\end{tabular}

The results show that knowledge creation is at the highest level and after that knowledge absorption, knowledge removal, knowledge dissemination, knowledge application, knowledge sharing, knowledge organization, knowledge evaluation, and knowledge storage are respectively in the next priorities.

Table 6.

T-test results of two independent samples for comparative study

\begin{tabular}{|l|l|c|c|c|c|}
\hline \multicolumn{2}{|c|}{ Variable's name } & Average & $\begin{array}{c}\text { Standard } \\
\text { deviation }\end{array}$ & $\begin{array}{c}\text { T-Test } \\
\text { statistics }\end{array}$ & $\begin{array}{c}\text { Significant } \\
\text { level }\end{array}$ \\
\hline cultural factors & $\begin{array}{l}\text { State-owned } \\
\text { banks }\end{array}$ & 3.68 & 0.572 & -2.61 & 0.009 \\
\cline { 2 - 4 } & $\begin{array}{l}\text { Private } \\
\text { banks }\end{array}$ & 3.85 & 0.664 & -1.99 & 0.047 \\
\hline $\begin{array}{l}\text { Participatory } \\
\text { Culture }\end{array}$ & $\begin{array}{l}\text { State-owned } \\
\text { banks }\end{array}$ & 3.99 & 0.566 & & \\
\cline { 2 - 4 } & $\begin{array}{l}\text { Private } \\
\text { banks }\end{array}$ & 4.12 & 0.646 & & \\
\hline $\begin{array}{l}\text { Culture of } \\
\text { trust-centered }\end{array}$ & $\begin{array}{l}\text { State-owned } \\
\text { banks }\end{array}$ & 3.91 & 0.565 & -2.13 & 0.034 \\
\hline
\end{tabular}




\begin{tabular}{|c|c|c|c|c|c|}
\hline & $\begin{array}{l}\text { Private } \\
\text { banks }\end{array}$ & 4.04 & 0.636 & & \\
\hline \multirow[t]{2}{*}{$\begin{array}{l}\text { Learning } \\
\text { culture }\end{array}$} & $\begin{array}{l}\text { State-owned } \\
\text { banks }\end{array}$ & 3.56 & 0.669 & \multirow{2}{*}{-2.89} & \multirow{2}{*}{0.004} \\
\hline & $\begin{array}{l}\text { Private } \\
\text { banks }\end{array}$ & 3.78 & 0.748 & & \\
\hline \multirow{2}{*}{$\begin{array}{l}\text { Customer } \\
\text { orientation } \\
\text { culture }\end{array}$} & $\begin{array}{l}\text { State-owned } \\
\text { banks }\end{array}$ & 3.37 & 0.837 & \multirow{2}{*}{-2.093} & \multirow{2}{*}{0.037} \\
\hline & $\begin{array}{l}\text { Private } \\
\text { banks }\end{array}$ & 3.56 & 0.915 & & \\
\hline \multirow{2}{*}{$\begin{array}{l}\text { Knowledge- } \\
\text { driven } \\
\text { leadership }\end{array}$} & $\begin{array}{l}\text { State-owned } \\
\text { banks }\end{array}$ & 3.59 & 0.750 & \multirow{2}{*}{-2.132} & \multirow{2}{*}{0.034} \\
\hline & $\begin{array}{l}\text { Private } \\
\text { banks }\end{array}$ & 3.78 & 0.862 & & \\
\hline
\end{tabular}

To compare the status of cultural factors and its sub-indicators among public and private banks, the average indicators between the two communities were compared, and the results obtained from the table showed that: In the model, the t-statistic calculated at the level of 0.05 is significant. Comparing the average of these factors shows that the situation of cultural factors and its sub-indicators among private banks are better (higher) than the State-owned in Khorasan Razavi province. In general, considering the higher average in both communities shows that the situation of cultural factors and its sub-indicators is favorable. 
Table 7.

Priority of ranking

\begin{tabular}{|c|c|c|}
\hline $\begin{array}{c}\text { Average ratings in private } \\
\text { banks }\end{array}$ & Variable & $\begin{array}{c}\text { Average ratings in state- } \\
\text { owned banks }\end{array}$ \\
\hline 3.81 & Participatory culture & 3.88 \\
\hline 3.42 & Trust-based culture & 3.57 \\
\hline 2.99 & Knowledge-driven leadership & 1.93 \\
\hline 2.54 & Learning culture & 2.18 \\
\hline 2.23 & Customer-oriented culture & \\
\hline
\end{tabular}

The results show that participatory culture is at the highest level and then trust-based culture, knowledge-based leadership, learning culture, and customer orientation culture are respectively in the next priorities.

Providing a desirable model and measuring the validity of the model for the implementation of cultural factors with a knowledge management approach in stateowned and private banks in Khorasan Razavi province.

Table 8.

Model fit indicators

\begin{tabular}{|l|c|c|}
\hline \multicolumn{2}{|c|}{ Fit indicators } & Values of indicators \\
\hline The root of the average of approximations & RMSEA & $0 / 051$ \\
\hline The root of the average errors & RMR & $0 / 044$ \\
\hline The relative value of variances and covariances & GFI & $0 / 84$ \\
\hline The same adjusted value of the GFI index & AGFI & $0 / 87$ \\
\hline
\end{tabular}

Here, the value of the model fitness index (RMSEA) is equal to 0.051 , which is close to 0.05 . It can be said that the index has a full fit and because the fit is not fully confirmed by this index, the fit of the model is measured by other indicators which these indicators are as follows: (RMR) index: This index is equal to 0.044 , which is relatively small and the model has a small error and the fit of the model is acceptable. (GFI) Index: This index is equal to 0.84, which is very close to 1 and shows that the model has an acceptable fit with the data. (AGFI) Index: This index is equal to 0.87 , which is very close to 1 and shows that the model has a good fit. In Confirmatory factor analysis questions with operating loads, less than 0.3 are not sufficient to remain in the model and must be removed and run again the model. In the table above, the values of the operating loads are all above 0.3 , and as a result, the next step is performed. 


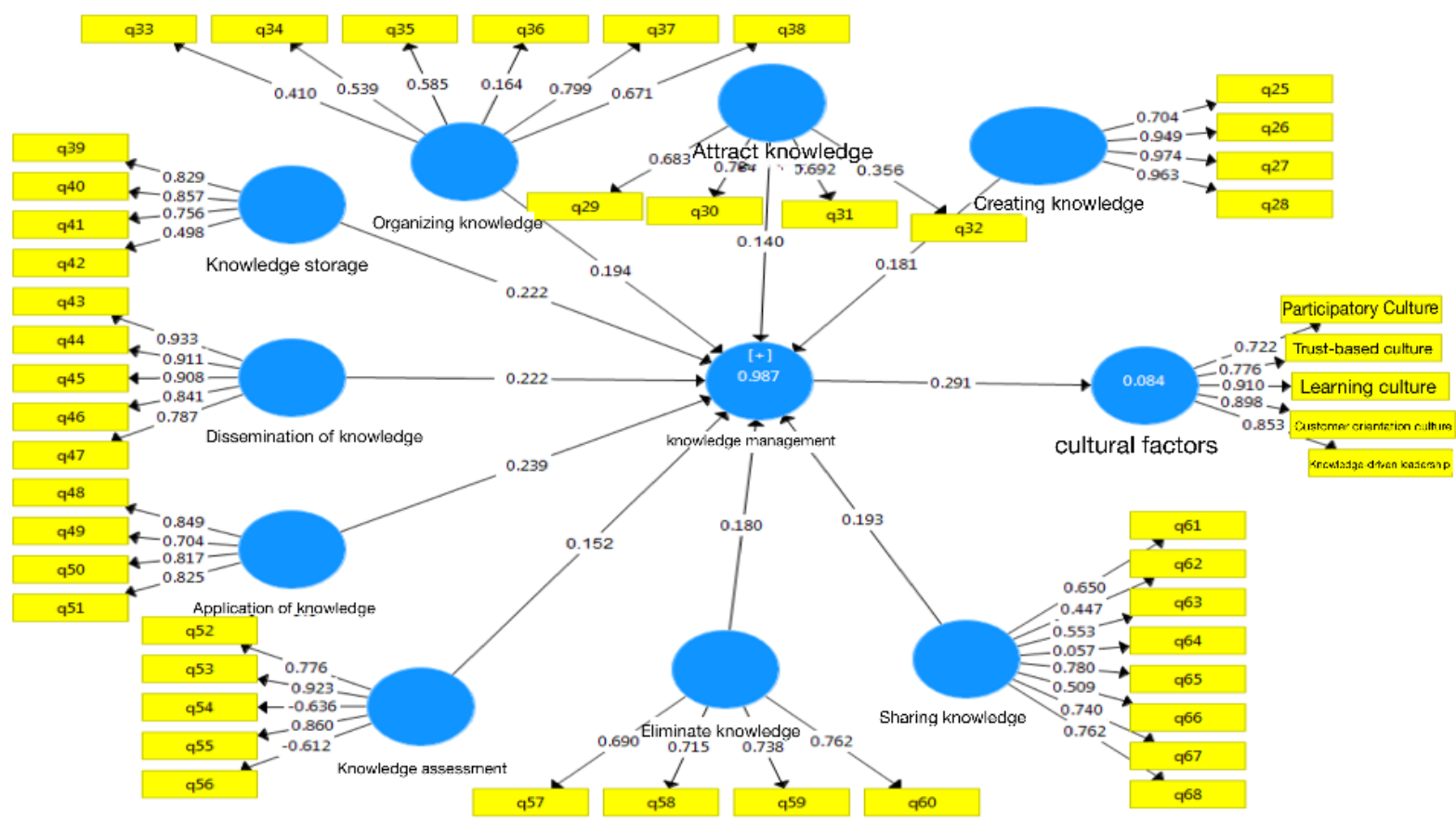

Figure 1.

Factors of factor loads in the study of factors

\section{Conclusion}

Today, in organizations, knowledge management is an important and vital issue, and by using knowledge management systems, long-term competitive advantage can be continued. "The key to the success of organizations in the current era is knowledge management," says Peter Drucker. Therefore, the implementation of knowledge management is necessary and institutions must plan to implement it. Knowledge management needs to be in harmony with the existing organizational culture in order to be usable because in any organization there is a unique culture of that organization that shows people how to understand and give meaning to events. Therefore, organizational culture can be used as a powerful lever to strengthen organizational behavior. Poor organizational culture prevents people from sharing and disseminating their knowledge in an effort to maintain their personal power base and efficiency. Therefore, the management of organizations should rely on superior knowledge to be able to make more sensible decisions on important issues and improve knowledge-based practices. Therefore, knowledge management is a more important category than knowledge itself, which in organizations seeks to explain and clarify how to turn personal and organizational information and knowledge, into individual and group knowledge and skills. Therefore, organizations need to create an environment for sharing, transferring, and exchanging knowledge among members and educating individuals to understand their interactions. It is only by examining, changing, and creating an appropriate and flexible organizational culture that one can gradually change the pattern of interaction between individuals in the organization and use knowledge management as a competitive advantage.

\section{Factors related to organizational culture and knowledge management}

Factors related to knowledge management are categorized in 9 dimensions and factors related to organizational culture are categorized in 5 dimensions, which in similar studies by Milani et al. (2019), Mohammad Esmaili (2018), Gorgie (2002), Fatahi (2016), Antunes and Pinheiro 
(2019), Antonio et.al. (2017), Linder and Wald (2010), Valmohammadi (2010), wang and Aspinoal (2005) has been obtained.

\section{A comparative study of cultural factors and knowledge management among public and private banks}

A review of the results showed that cultural factors and their sub-indicators in private banks are in a better position than in the state-owned sector. Knowledge management and its subindicators, except for sub-indicators of knowledge creation between public and private banks, have no significant difference and in the index of knowledge creation private banks are in a better situation than in the state-owned banks.

\section{References}

Abili, K., Naderi, A., Orei Yazdani, B., \& Nastizai, N. (2014). Designing a Participatory Management Model, General Management Research, 6(21), 122-101.

Allameh, S. M., \& Asgari Bajgrani, M. (2017). Pathology of Organizational Culture and Identification of Requirements for its Change in Isfahan Regional Electricity Company, Organizational Culture Management, 15(3), 575-603.

Antunes, H. d. J. G., \& Pinheiro, P.G. (2019). Linking knowledge management, organizational learning, and memory. Journal of Innovation \& Knowledge, 4(1), 178-190. https://doi.org/10.1016/j.jik.2019.04.002.

Calipha, R., Brock David, M., Rosenfeld, A., \& Dvir, D. (2018). "Acquired, transferred and integrated knowledge: a study of M\&A knowledge performance". Journal of strategy and Management, 11(3), 282-305

Daniel, R., \& Gretchen, M. (1991). "Organizational Culture and Organizational Development: A Competing Values Approach". Research in Organizational Change and Development, 5, 78-91.

Debowski, S. (2006). Knowledge Management. Milton: John Wiley \& Sons.

Dehmardeh, M., \& Nastizi, N. (2019). A Study of the Impact of Organizational Trust on Organizational Commitment through the Mediation of Organizational Participation, General Management Research, 12(44), 56-77.

Denison, D. R. (2000). Organizational culture: Can it be a key lever for driving organizational change. The handbook of organizational culture. London: John Wiley \& Sons.

Ebrahimi, M. (2018). Factors Affecting the Application of Knowledge Management at Mohaghegh Ardabili University, Master Thesis, Ardabil University.

Fadaei, G., Naghshineh, N., \& Andishesh, S. (2017). A Study of the Relationship between Organizational Culture and Knowledge Management at the University of Tehran, Quarterly Journal of Library and Information Science Studies, 24, 128-103.

Fong Boh, W., Nguyen, T.T., \& Xu, Y. (2013). "Knowledge transfer across dissimilar cultures". Journal of Knowledge Management. 17(1), 29-46.

Francesca, D.M, Michael, R., Andrea, G., \& Maurizio, M. (2018). Towards a Social Knowledge Management in a Knowledge-Intensive Public Organization, See discussions, stats, and 
author profiles for this publication at https://www.researchgate.net/publication/328956831.

Kheiri, M. (2017). Implementation and establishment of knowledge codification in the organization, 4th International Conference on Management, Entrepreneurship and Economic Development.

Laitinen, E. K., \& Suvaz, A. (2016). Financial distress prediction in an international context: Moderating effects of Hofsted's original cultural dimensión. Journal of Behavioral and Experimental Finance, 9, 98-118.

Milani, O. (2015). A Study of the Relationship between Participatory Culture and Knowledge Management and Their Impact on Organizational Development,. Educational Management Innovations, 25, 32-50.

Mohammad Asmaili, N. (2018). Identification of mechanisms for developing a customeroriented culture in the organization. Public Research, 11(39), 273-249.

Nazari, M. (2019). A Study of the Relationship between Organizational Culture and Knowledge Management Components in Educational Organizations, 3rd International Conference on Innovation and Research in Educational Sciences, Management and Psychology, Tehran.

Osanloo, B., \& Moheban, A. (2017). A Study of the Impact of Organizational Culture on Knowledge Management Based on Denison Organizational Culture Model, 2nd International Conference on Industrial Management, University of Mazandaran.

Schobel, M. (2017). Digging deeper! Insights from a multi-method assessment of safety culture in nuclear power plants based on Schein's culture model, Safety Science, 5, 38-49.

Shapiro, B., \& Naughton, M. (2015). The expression of espoused humanization values in organizational practice: a conceptual framework and case study. Journal of business ethics, (126), 65-81.

Skerlavaj, M. (2010). Organizational learning culture, innovative culture, and innovations in South Korean firms. Journal of Expert Systems with Applications, 37, 6390-6403. 